\title{
A SHORT STROLL IN A DESERT PLACE
}

\author{
MAJOR R. N. P. SUTTON, M.A., D.M., D.Sc., M.R.C.Path., D.C.H., \\ R.A.M.C.(V)
}

Withington Hospital, Manchester

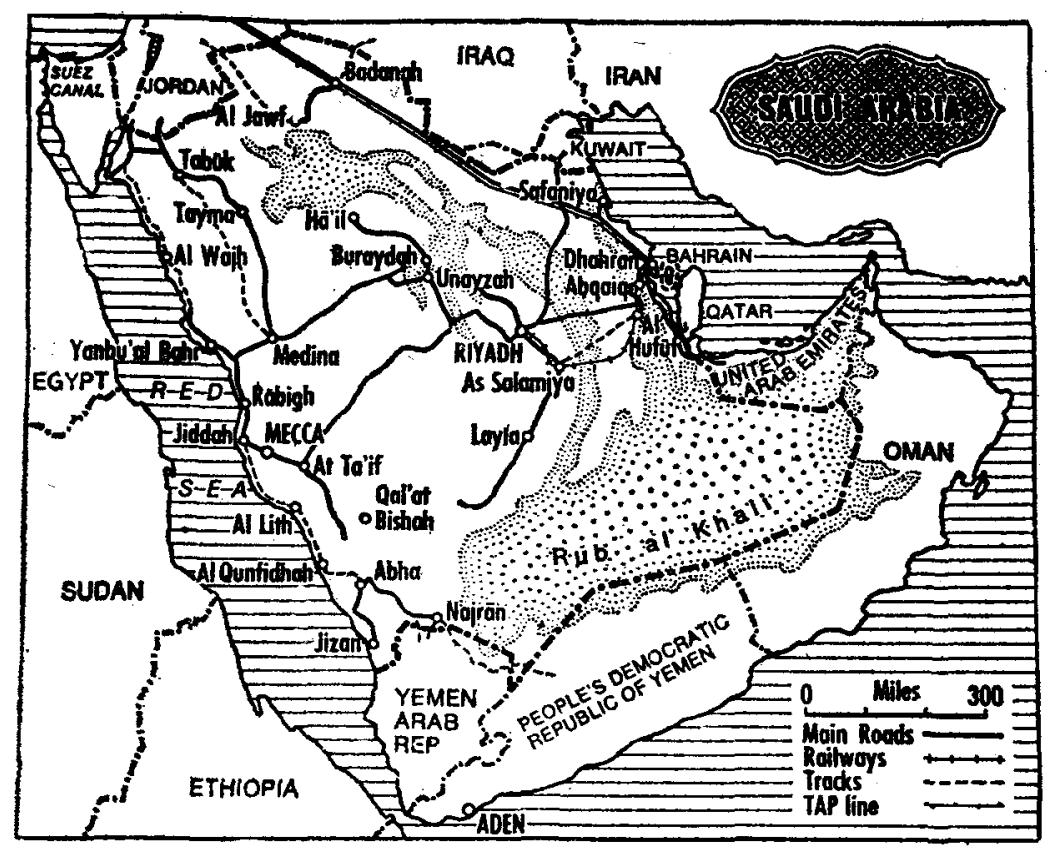

Map of Saudi Arabia

My entry to the Arab world was through the doorway of the Saudi Airways Boeing 727-for this must be the only airline where no alcohol is available; so, within minutes, one comes in contact with the strict interpretation of the Islamic code, the Sharia, and call to mind the Wahhabi influence. The flight runs over Cyprus and via Syria and the Gulf to Dharan on the East Coast of Arabia; Dharan airport is in an interesting moorish style and leaves one in no doubt that one is in the Middle East. The flight to Riyadh, some 500 miles away, lies over desert. Apart from the occasional trunk road, pipeline or oil installation, by day the desert stretches away but it is not entirely featureless. Wadis and hillocks are evident and the general appearance from the air is not unlike the beach at Weston-super-Mare when the tide has gone out, swirls of sand being evident with the occasional patches of greenery whether seaweed or palm trees. By night, the flares from the oil fields spread from horizon to horizon, much like the blast furnaces around Sheffield in the days before the electric open hearth process of steel smelting was introduced. 


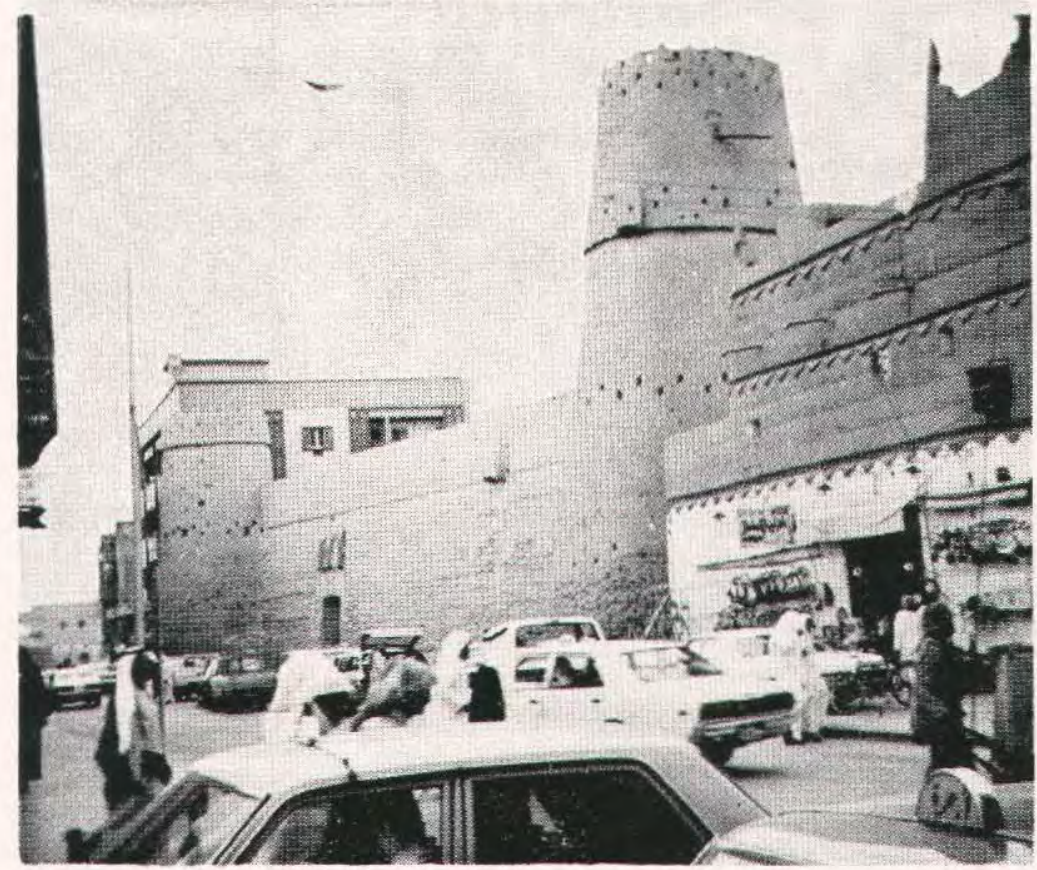

Central Riyadh

I was met at Riyadh by two members of the faculty of medicine, and soon found myself in the Al Yamama Hotel. Al Yamama means Turtle Dove and this hotel is one of the largest and best known in Riyadh. Tourism is not practicable in Arabia and the clientele of the hotel are business men of many-I once counted eleven at one time - nationalities. They are involved in every angle of trade. For example, once upon a time, a Saudi Arabian military band committeed a musical faux-pas and dried up in the middle of the national anthem being played to honour a visiting potentate - and now, Messrs. Boosey and Hawkes have added Saudi Arabia to their list of customers for instruments, training and music; Israeli and Arab armies thus march behind bands furnished by the same firm. A Lebanese surveyor had a bundle of plans for an irrigation project to be laid out at a spot somewhere in the North and, at present, uninhabited and unknown other than by a map reference. A Japanese press tycoon received the accolade of a full page spread in the duplicated English language Riyadh Daily News; the local press authorities took him out by car to a desert feast (rice, lamb and fruit) some fifteen miles out of Riyadh. In and out of these expatriates swept the local men in power and the contact men, in gold edged robes and head cloths of white, chequered in red, blue or black, drinking endless tiny cups of weak Arabian coffee and idly playing with their beads. Many of these in state employ would be related to the present ruler, not a difficult task as his grandfather Ibn Saud had about 300 wives at one time or another and so the present ruler must have at least that number of uncles and cousins, most of whom are in government service. I should mention 
that the government of Saudi Arabia is an absolute monarchy with no nonsense about representative government. However, all subjects have the opportunity to meet the King at his weekly general meetings, which clearly stem from the desert traditions of the majlis. The Government departments have simply evolved from departments of Ibn Saud's household. Thus the treasury evolved from Ibn Saud's privy purse which was held by a trusted slave as recently as the 1930s. There are now no slaves-slavery was abolished as long ago as 1963. The nationalised airline developed from Ibn Saud's private fleet of aircraft and, in recent time, the most unusual people were seen on Saudi Airline's planes, for all members of Ibn Saud's household had the privilege of free tickets. Since World War II, Ministries of Petroleum, Armed Services and so on have developed. These are housed in splendid premises along the road to the airport and mostly under the control of relatives of the present king, although there are a few exceptions to this rule.

As a town, Riyadh is a mixture of old and new. The walls have recently been dismantled and only a few of the old buildings remain, for example, the Musmak and the palace of Princess Nura, she who escaped from Riyadh with her brother Ibn Saud slung in camel bags. The minarets are noticeable, being shorter and squatter than those of other Islamic countries. Women are not seen out commonly and those that are seen are almost invariably veiled. Under the veils, they are mini-skirted and quite up to date and it is only the immigrant women from the Yemen and the Hadhramaut who still paint their hands with blue dye or with henna and even this is not often seen.

When out visiting, there may be two types of welcome. In one, probably the commoner, you would be asked to wait a moment on the threshold and in the background there is a tantalizing flash of pink or green-when you are let in, the harem are safely away and, with the men, you can talk, over weak tea with mint or cardamom seeds, usually about politics and watch the television. Or, if you are luckier, the harem will stay but perhaps a young female friend of the family may have to slip off to obtain parental permission to meet a strange man. Pink cakes and tea again and chatter-we must remember that it is only a couple of decades since women's education was introduced and Saudi Arabia and the imams, the religious authorities, at that time considered that women's education could not be harmful if it were not prolonged beyond the age of about nine or ten. At that time, they also considered that it could not harm women's modesty for her to hear a male voice over the telephone. There are some advantages to such a sheltered upbringing, for I do not think that in the enlightened West, the daughter of the house would carry in, for a middle aged visitor, a handful of jasmine petals from the garden in order to perfume the hot night air.

My object, in visiting Saudi Arabia, was not, however delightful, to bask in domesticity and absorb the compliments of the harem but to teach Saudi medical students, the first batch of which are in process of being trained. I gave two courses on Virology to medical students and students of Pharmacy. This teaching was carried out in a bacteriological laboratory of the Pharmacy school, a small building, built around a shaded courtyard, and I found the students of both faculties very intelligent and attentive. I gave a couple of lectures in the Riyadh 
General Hospital and visited the Central Public Health Laboratory. The hospital was interesting in that women were employed there, as nurses and doctors; although, when I talked, they sat at the back of the lecture theatre and spoke not at all.

At the level of the laboratory bench, the problems are those which one might expect in a Middle Eastern country. Salmonellosis is rife in faecal specimens from normal inhabitants of Saudi Arabia 9 to 11 per cent of those tested had salmonellae present and up to 25 per cent of the population carried shigellae. In the light of these findings, attempts are being made to control food handlers. There is a small virus laboratory and, although this deals with much the same kind of material as similar laboratories in this country there are some local problems. Cases of smallpox have been seen over the past few years and many of these were diagnosed clinically as other conditions, for example, chicken pox, meningoccal septicaemia or atypical smallpox. Rabies is also a problem and there are perhaps 20 to 25 confirmed cases of rabies each year in Saudi Arabia, equally distributed between camels and foxes. Human rabies is infrequent but the presence of animal reservoirs of infection means that the risk is always present. A third problem is encephalitis and fevers of unknown aetiology. Here, the possibility of arbovirus infections is clear, although few investigations have been carried out in this field.

A friend of H. St. John Philby spent some while in looking for the Arabian oryx, the real but rare animal which gave origin to the mythical unicorn. Referring to his quest, he wrote "The Treasure is nothing compared with the hunt". I spent a number of pleasant hours in finding, out something about the country which I visited for a short while: I hope that the results bear some interest.

F.R.C.S.Ed.

M.R.C.P.

M.R.C.G.P.

M.R.C.Path. M.R.C.Psych.

D.Obst.R.C.O.G.

\section{ACADEMIC ACHIEVEMENTS}

MAJOR J. P. J. O'DONOVAN, M.B., B.S., M.R.C.S., L.R.C.P., R.A.M.C.

MAJOR G. O. HOPKINS, M.B., B.S., M.R.C.S., L.R.C.P., D.PhysMed., R.A.M.C.

CAPTAIN P. C. MITCHELL, M.B., B.S., D.Obst.R.C.O.G., R.A.M.C.

MAJOR J. JOHNSTON, M.B., Ch.B., R.A.M.C.

MAJOR P. J. W. WOOD, M.B., B.S., M.R.C.S., L.R.C.P., D.P.M., R.A.M.C.

CAPTAIN P. K. LAWRENCE, B.A., M.B., B.Ch., B.A.O., R.A.M.C.

CAPTAIN B. L. B. LOBBAN, M.B., Ch.B., R.A.M.C. 